\title{
VARIATION IN INTRON 1 OF THE OVINE GDF8 GENE AND ITS ASSOCIATION WITH GROWTH AND CARCASS CHARACTERISTICS OF DUAL PURPOSE SHEEP
}

\author{
A. H. M. Ibrahim**1, H. Zhou ${ }^{2}$ and J.G.H. Hickford ${ }^{2}$ \\ 1- Department of Animal Breeding, Desert Research Center, 1 Mathaf AlMatariya St., Cairo, Egypt, 2- Gene- \\ Marker Laboratory, Agriculture and Life Sciences Division, P.O. Box 84, Lincoln University, Canterbury, \\ New Zealand \\ *Email: adelhosseiny2005@yahoo.com
}

\section{SUMMARY}

The aim of this study was to further investigate the variation in growth and differentiation factor $8(G D F 8)$ gene and its association with growth and carcass characteristics of New Zealand Romney sheep. Polymerase chain reaction-single strand conformational polymorphism (PCR-SSCP) analysis was used to detect the polymorphisms in intron 1 of ovine GDF8 gene in $447 \mathrm{New}$ Zealand Romney lambs produced from 17 sire-lines. PCR-SSCP analysis identified a total of six SSCP genotypes, AA (0.111), AB (0.367), AC (0.100), BB (0.288), $B C(0.128)$ and $C C(0.006)$ representing three alleles $A, B$ and $C$ with frequency of $0.34,0.54$ and 0.12 , respectively. General linear mixed effect models revealed a significant effect $(P<0.05)$ for GDF8 genotype on loin yield and percentage loin yield. The presence of allele $B$ was significantly associated with increased loin yield $(P<0.05)$ and percentage loin yield $(P<0.01)$. Effects of number of allele copies present on the studied traits were assessed. Loin yield and percentage loin yield were significantly $(P<0.05)$ affected by number of allele B copies. Having one copy of allele B was associated with increased loin yield, total yield and percentage loin yield; however, having two copies of allele B was associated with decreased loin yield and total yield. Our present results suggest that GDF8 polymorphism is mainly associated with loin yield and percentage loin yield and has no effect on birth weight, weaning weight and growth rate in New Zealand Romney sheep.

Keywords: growth, carcass, GDF8, PCR-SSCP, Romney sheep

\section{INTRODUCTION}

The identification of genes that affect economically important traits for sheep meat would improve selective breeding programs for sheep production. Growth and differentiation factor 8 (GDF8) is one such gene. It is a member of the transforming growth factor $\beta$ (GDF8 $\beta$ ) superfamily. The members of this family regulate cell growth and differentiation in both embryonic and adult tissues. GDF8 is highly expressed in developing and adult muscles and acts as a negative regulatory factor by inhibiting MYF5 and MyoD two factors involved in the differentiation of muscle precursor cells into myoblasts (McPherron et al., 1997).

GDF8 loss-off function leads to increase skeletal muscle mass (double muscling) in mice (McPherron et al., 1997; Szabo et al., 1998; Lin et al., 2002; Whittemore et al., 2003 and Mendias et al., 2008). While variation in other species including cattle (McPherron and Lee, 1997; Grobet et al., 1997; Kambadur et al., 1997; Wiener et al., 2002; Marchitelli et al., 2003 and Grisolia et al., 2009), Sheep (Clop et al., 2006; Kijas et al., 2007; Hickford et al., 2009; Han et al., 2010 and Haynes et al., 2013) and human (Schuelke et al., 2004) is reported to affect muscling. In addition, GDF8 deficiency in mice reduces adipogensis (Lin et al., 2002; McPherron and Lee, 2002), as a result of reduced production and secretion of leptin (McPherron and Lee, 2002). The effect of GDF8 on myogenic and adipogenic differentiation potentially has important implications for growth and carcass traits of sheep. The ovine GDF8 gene consists of three exons and two introns (Bellinge et al., 2005) and located on chromosome 2.

Variation in the ovine GDF8 gene and its effect on important production traits in sheep has been described in a number of reports. For example a single nucleotide polymorphism (SNP; g.6223G $>$ A) has been detected in the 3'- UTR of GDF8 gene in Belgian Texel sheep (Clop et al., 2006). The same SNP was also detected in other breeds including Australian Texel sheep (Kijas et al., 2007), Charollais sheep (Hadjipavlou et al., 2008), New Zealand Texel sheep (Johnson et al., 2009) and White Suffolk, Poll Dorest and Lincoln sheep in Australia (Kijas et al., 2007). This SNP has been found to affect muscle hypertrophy in Belgian Texel sheep (Clop et al., 2006), muscle depth in Charollais sheep (Hadjipavlou et al., 2008) and birth weight, mean lean yield and total muscle yield in New

Issued by The Egyptian Society of Animal Production 
Zealand Romney sheep (Han et al., 2010). Additional SNPs $\left(g^{-} 41 \mathrm{C}>\mathrm{A}, \mathrm{g}^{+} 4036 \mathrm{~A}>\mathrm{C}\right.$ and $\mathrm{g}^{+}$6223G $>\mathrm{A}$ ) have been identified in the promoter and intron 2 regions and showed significant effects on slaughter measurements of muscling and fatness (Kijas et al., 2007). Additional two SNPs (C.2360G $>$ A and C.960delG) have been detected and are reported to reduce fatness and increase muscle mass in Norwegian White sheep (Boman et al., 2010). A single strand conformational polymorphism analysis (SSCP) of the 473-bp of the exon 1- intron 1 region of GDF8 gene has revealed three allelic variants in NZ Romney sheep (Zhou et al., 2008). In the same breed, five SSCP allelic variants have been detected in intron 1 region of GDF8 gene and showed significant effects on leg yield, loin yield, loin yield $\%$ and total yield (Hickford et al., 2009).

The objective of the present study was to further investigate allelic variants of intron 1 of the ovine GDF8 gene and to test their association with growth and carcass traits in New Zealand Romney sheep.

\section{MATERIALS AND METHODS}

\section{Animals and data collection}

A total of 447 male Romney lambs produced by 17 unrelated NZ Romney rams were used to detect the allelic variation in intron 1 of GDF8 and then to test the association of the variants with growth and carcass traits for Romney sheep.

Birth date, birth rank (i.e. whether they were single, twin or triple) and gender were recorded at birth. Subsequently, the growth data were collected including birth weight, weaning weight, weaning age, pre-weaning growth rate (calculated as the difference between weaning weight and birth weight divided by age in days; expressed in grams/day), and weight and age at selection (on farm) for slaughter.

Hot carcass weight (HCW) was measured directly on the processing chain. HCW is the weight in kilograms of the carcass components minus the pelt, head and gut. Video imaging analysis (VIASCAN@Sastek), developed by Meat and Livestock Australia and described by Hopkins et al. (2004), was used to estimate the following carcass traits: lean meat yield (expressed as a percentage of $\mathrm{HCW}$ ) in the leg (leg yield), loin (loin yield) and shoulder (shoulder yield), total yield (the sum of the leg, loin and shoulder yields for any given carcass), the proportion leg yield, the proportion loin yield and the proportion shoulder yield. The proportion yield of leg, loin or shoulder is the yield of the specific area, divided by the total yield expressed as a percentage.

\section{DNA purification and genotyping}

Blood samples were collected on FTA cards. For each sample, a disc of $1.2 \mathrm{~mm}$ in diameter was punched and the genomic DNA was purified from the dried blood spot using a two-step procedure described by Zhou et al. (2006).

A 414 bp fragment containing intron 1 of GDF8 gene was amplified using a pair of specific primers.
The sequences of these two primers are described in the report of Hickford et al. (2009) and are as follows: F: 5'-GAAACGGTCATTACCA-TGC-3' and R: 5'-CAT-ATTTCAGGCAACCAAATG-3'. PCR amplification was carried out in a total reaction volume of $20 \mu \mathrm{l}$ containing the genomic DNA on the FTA card, $0.25 \mu \mathrm{M}$ of each primer, $150 \mu \mathrm{M}$ of $\mathrm{Mg}^{++}$, $0.5 \mathrm{U}$ of Taq DNA polymerase and $1 \mathrm{x}$ reaction buffer supplied. The reaction conditions were as follow: an initial DNA template denaturation at $94 \mathrm{C}^{\circ}$ for $2 \mathrm{~min}$, followed by 35 cycles of denaturation at $94 \mathrm{C}^{\circ}$ for 30 sec; annealing at $61 \mathrm{C}^{\circ}$ for $30 \mathrm{sec}$, and extension at $72 \mathrm{C}^{\circ}$ for $40 \mathrm{sec}$ and final extension at $72 \mathrm{C}^{\circ}$ for 5 $\min$.

One $\mu \mathrm{l}$ of each amplicon was mixed with $10 \mu \mathrm{l}$ of loading dye ( $98 \%$ formamide, $10 \mathrm{mM}$ EDTA, $0.025 \%$ bromophenol blue, $0.025 \%$ xylene cyanol). After denaturation at $105 \mathrm{C}^{\circ}$ for $5 \mathrm{~min}$, samples were rapidly cooled on wet ice and then loaded on $12 \%$ acrylamide gels. Amplicons representive of the three known GDF8 alleles (Hickford et al., 2009) were also included in each polyacrylamide gel to use their banding patterns as a standard for determining the alleles present in individual lambs. Electrophoresis was performed using Protean IIxi cells (Bio-Rad), at $350 \mathrm{~V}$ and $12 \mathrm{C}^{\circ}$ for $18 \mathrm{~h}$ in $0.5 \mathrm{x}$ TBE buffer. Gels were silver-stained according to the method described by Byun et al. (2009).

\section{Statistical Analysis}

Data were analyzed using SPSS version 15 (SPSS Science Inc., Chicago, IL). The strength of the associations between the various traits was tested by calculating Pearson correlation coefficients. No traits were strongly correlated, so they were all tested independently.

General linear mixed effect models (GLMMs) were used to assess the effect of GDF8 genotypes (frequency $<1 \%$ ) on growth and carcass traits. GDF8 genotype and birth rank were fitted as fixed factors along with sire fitted as a random factor in each model. In the model assessing the genotype effect on weaning weight, weaning age was included as a covariate. Also, draft weight was included as a covariate in the model testing the effect of genotypes on draft age and $\mathrm{HCW}$.

The generalized statistical model used to test the genotype effect was (without the added covariates) as follows:

$$
Y_{i j k l}=\mu+t_{i}+\beta_{j}+\alpha_{k}+\epsilon_{i j k l}
$$

Where $\boldsymbol{Y}_{i j k l}=$ traits (birth weight, weaning weight, growth rate, etc); $\boldsymbol{\mu}=$ the overall mean for each trait; $\boldsymbol{t}_{\boldsymbol{i}}=$ the fixed effect of $i^{\text {th }}$ genotype; $\boldsymbol{\beta}_{j}=$ the fixed effect of $j^{\text {th }}$ birth rank; $\boldsymbol{\alpha}_{k}=$ the random effect of $k^{\text {th }}$ sire and $\boldsymbol{\epsilon}_{i j k l}=$ the random error for $i j k l$.

The GLMMs were used to explore the effect of the absence/presence of myostatin alleles on growth and carcass traits. For each trait, a GLMM was performed for each GDF8 allele observed in the population. Allele absence or presence (coded as 0 or 1 , respectively), and birth rank were fitted as fixed factors, whilst sire was fitted as a random factor in 
each model. Co-variates were fitted as described above.

A separate set of analyses was performed to test the effect of the number of allele copies present on growth and carcass traits. The GLMMs were conducted in an identical manner to the models used for testing the absence/presence of each allele. Similar to the absence/presence models, each allele was tested in separate models. Co-variates were fitted as described above.

Where significant $(\mathrm{P} \leq 0.05)$ or if tending towards significance $(0.05<\mathrm{P} \leq 0.1)$, these were further explored using pairwise comparisons (least significant difference).

\section{RESULTS AND DISCUSSION}

PCR-SSCP analysis of intron 1 of the GDF8 gene in New Zealand Romney sheep revealed only three alleles (A, B and C) with frequency of 0.34 , 0.54 and 0.12 , respectively. Six genotypes were observed in the genotyped lambs including AA (0.111), AB (0.367), AC (0.100), BB (0.288), BC (0.128) and CC (0.006). Fifteen SSCP genotypes representing five alleles $(\mathrm{A}, \mathrm{B}, \mathrm{C}, \mathrm{D}$ and $\mathrm{E})$ were detected in a variety of breeds and composite breeds in New Zealand. Variation in the same region of New Zealand Romney sheep has been also described by Hickford et al. (2009). They also reported six GDF8 genotypes AA (0.466), AB (0.302), AC (0.133), BB (0.058), BC (0.035) and $\mathrm{CC}(0.06)$, derived from three alleles A (0.683), B (0.227) and C (0.09).
PCR-SSCP analysis proved to be a robust tool to detect the mutation in GDF8 gene in sheep using gene sequence information to construct the primers and also could be used to screen a large number of samples because of its low price, speedy and easy handling.

To assess the effect of GDF8 genotype on growth and carcass traits, only the common genotypes $\mathrm{AA}, \mathrm{AB}$. AC, BB and $\mathrm{BC}$ were included, as the frequency of $\mathrm{CC}$ was less than $1 \%$. No associations were found between GDF8 genotypes and birth weight, weaning weight, growth rate or draft-age. The GLMM results (Table 1) suggested a significant effect $(\mathrm{P}<0.05)$ for the genotype on loin yield and percentage loin yield. In addition, GLMMs suggested an association, although not significant ( $\mathrm{P}$ $<0.095$ ), between total yield and genotype. Least square mean results showed that lambs with the genotype $\mathrm{BC}$ had the highest mean and lambs with the genotype $\mathrm{AC}$ had the lowest mean for loin yield and total yield. Also, the genotype $\mathrm{BC}$ had the highest mean and the genotype AA had the lowest mean for percentage loin yield. Pairwise comparison results indicated that the lambs with the genotype BC were higher $(\mathrm{P}<0.05)$ than the lambs with the genotype AA. These results are partially consistent with the observations made by Hickford et al. (2009) who found that GDF8 genotypes significantly affected leg yield, loin yield, total yield and the percentage loin yield.

Table 1. The effect of GDF8 genotype on various assessments of yield

\begin{tabular}{lcccccc}
\hline & \multicolumn{7}{c}{$\mathbf{L S M} \pm \mathbf{S E}$} & & \\
\cline { 2 - 6 } Trait & $\mathbf{A A}(\mathbf{n}=\mathbf{4 9})$ & $\mathbf{A B}(\mathbf{n}=\mathbf{1 7 1})$ & $\mathbf{A C}(\mathbf{n}=\mathbf{4 7})$ & $\mathbf{B B}(\mathbf{n}=\mathbf{1 3 9})$ & $\mathbf{B C}(\mathbf{n}=\mathbf{6 3})$ & value \\
\hline $\begin{array}{l}\text { Leg Yield (Kg) } \\
\text { Loin Yield (Kg) }\end{array}$ & $21.810 \pm 0.160$ & $21.696 \pm 0.093$ & $21.456 \pm 0.158$ & $21.497 \pm 0.100$ & $21.678 \pm 0.144$ & 0.214 \\
$\begin{array}{l}\text { Shoulder Yield } \\
\text { (Kg) }\end{array}$ & $17.544 \pm 0.125$ & $17.532 \pm 0.072$ & $17.336 \pm 0.123$ & $17.407 \pm 0.078$ & $17.528 \pm 0.112$ & 0.425 \\
$\begin{array}{l}\text { Total Yield } \\
\text { (Kg) }\end{array}$ & $54.030 \pm 0.342$ & $54.039 \pm 0.199$ & $53.385 \pm 0.338$ & $53.535 \pm 0.213$ & $54.182 \pm 0.308$ & 0.095 \\
$\begin{array}{l}\text { Leg Yield \% } \\
\text { Loin Yield \% }\end{array}$ & $0.403 \pm 0.001$ & $0.401 \pm 0.001$ & $0.402 \pm 0.001$ & $0.401 \pm 0.001$ & $0.400 \pm 0.001$ & 0.436 \\
$\begin{array}{l}\text { Shoulder Yield } \\
\text { \% }\end{array}$ & $0.325 \pm 0.002$ & $0.325 \pm 0.001$ & $0.325 \pm 0.002$ & $0.325 \pm 0.001$ & $0.323 \pm 0.001$ & 0.790 \\
\hline
\end{tabular}


Table 2. Association of GDF8 alleles with various assessments of yield

\begin{tabular}{|c|c|c|c|c|c|c|c|}
\hline \multirow[b]{2}{*}{ Trait } & \multirow{2}{*}{$\begin{array}{c}\text { Allele } \\
\text { being } \\
\text { assessed }\end{array}$} & \multirow{2}{*}{$\begin{array}{c}\text { Other } \\
\text { alleles in } \\
\text { model }\end{array}$} & \multicolumn{4}{|c|}{$\mathrm{LSM} \pm \mathrm{SE}$} & \multirow[b]{2}{*}{ P-value } \\
\hline & & & Allele absent & $\mathbf{N}$ & Allele present & $\mathbf{N}$ & \\
\hline \multirow[t]{6}{*}{ Leg yield (Kg) } & $\mathrm{A}$ & None & $21.567 \pm 0.088$ & 204 & $21.672 \pm 0.081$ & 267 & 0.267 \\
\hline & B & None & $21.646 \pm 0.117$ & 98 & $21.621 \pm 0.731$ & 373 & 0.834 \\
\hline & $\mathrm{C}$ & None & $21.635 \pm 0.074$ & 359 & $21.596 \pm 0.115$ & 112 & 0.743 \\
\hline & A & $\mathrm{B}, \mathrm{C}$ & $21.547 \pm 0.110$ & 204 & $21.663 \pm 0.089$ & 267 & 0.293 \\
\hline & B & $\mathrm{A}, \mathrm{C}$ & $21.588 \pm 0.129$ & 98 & $21.622 \pm 0.086$ & 373 & 0.811 \\
\hline & $\mathrm{C}$ & $\mathrm{A}, \mathrm{B}$ & $21.611 \pm 0.096$ & 359 & $21.599 \pm 0.115$ & 112 & 0.932 \\
\hline \multirow[t]{6}{*}{ Loin yield (Kg) } & A & None & $14.743 \pm 0.069$ & 204 & $14.748 \pm 0.063$ & 267 & 0.945 \\
\hline & B & None & $14.644 \pm 0.092$ & 98 & $14.771 \pm 0.057$ & 373 & 0.166 \\
\hline & $\mathrm{C}$ & None & $14.725 \pm 0.058$ & 359 & $14.820 \pm 0.090$ & 112 & 0.303 \\
\hline & A & $\mathrm{B}, \mathrm{C}$ & $14.660 \pm 0.085$ & 204 & $14.771 \pm 0.070$ & 267 & 0.200 \\
\hline & B & $\mathrm{A}, \mathrm{C}$ & $14.591 \pm 0.101$ & 98 & $14.841 \pm 0.067$ & 373 & 0.026 \\
\hline & $\mathrm{C}$ & $\mathrm{A}, \mathrm{B}$ & $14.620 \pm 0.075$ & 359 & $14.812 \pm 0.090$ & 112 & 0.059 \\
\hline \multirow{6}{*}{$\begin{array}{l}\text { Shoulder yield } \\
(\mathrm{Kg})\end{array}$} & A & None & $17.450 \pm 0.068$ & 204 & $17.497 \pm 0.063$ & 267 & 0.518 \\
\hline & B & None & $17.445 \pm 0.091$ & 98 & $17.484 \pm 0.057$ & 373 & 0.669 \\
\hline & $\mathrm{C}$ & None & $17.484 \pm 0.058$ & 359 & $17.450 \pm 0.089$ & 112 & 0.708 \\
\hline & A & $\mathrm{B}, \mathrm{C}$ & $17.409 \pm 0.085$ & 204 & $17.486 \pm 0.070$ & 267 & 0.374 \\
\hline & B & $\mathrm{A}, \mathrm{C}$ & $17.407 \pm 0.101$ & 98 & $17.488 \pm 0.067$ & 373 & 0.469 \\
\hline & $\mathrm{C}$ & A, B & $17.446 \pm 0.075$ & 359 & $17.449 \pm 0.089$ & 112 & 0.975 \\
\hline \multirow[t]{6}{*}{ Total yield (Kg) } & A & None & $53.759 \pm 0.188$ & 204 & $53.919 \pm 0.173$ & 267 & 0.436 \\
\hline & $\mathrm{B}$ & None & $53.735 \pm 0.251$ & 98 & $53.876 \pm 0.156$ & 373 & 0.575 \\
\hline & $\mathrm{C}$ & None & $53.844 \pm 0.159$ & 359 & $53.866 \pm 0.246$ & 112 & 0.932 \\
\hline & A & $\mathrm{B}, \mathrm{C}$ & $53.616 \pm 0.235$ & 204 & $53.921 \pm 0.191$ & 267 & 0.200 \\
\hline & $\mathrm{B}$ & $\mathrm{A}, \mathrm{C}$ & $53.587 \pm 0.277$ & 98 & $53.951 \pm 0.185$ & 373 & 0.237 \\
\hline & $\mathrm{C}$ & $\mathrm{A}, \mathrm{B}$ & $53.677 \pm 0.205$ & 359 & $53.681 \pm 0.246$ & 112 & 0.510 \\
\hline \multirow[t]{6}{*}{ Leg yield \% } & A & None & $0.401 \pm 0.001$ & 204 & $0.402 \pm 0.001$ & 267 & 0.299 \\
\hline & $\mathrm{B}$ & None & $0.403 \pm 0.001$ & 98 & $0.401 \pm 0.001$ & 373 & 0.173 \\
\hline & $\mathrm{C}$ & None & $0.402 \pm 0.001$ & 359 & $0.401 \pm 0.001$ & 112 & 0.406 \\
\hline & A & $\mathrm{B}, \mathrm{C}$ & $0.402 \pm 0.001$ & 204 & $0.402 \pm 0.001$ & 267 & 0.926 \\
\hline & $\mathrm{B}$ & $\mathrm{A}, \mathrm{C}$ & $0.402 \pm 0.001$ & 98 & $0.401 \pm 0.001$ & 373 & 0.147 \\
\hline & $\mathrm{C}$ & A, B & $0.402 \pm 0.001$ & 359 & $0.401 \pm 0.001$ & 112 & 0.205 \\
\hline \multirow[t]{6}{*}{ Loin yield \% } & A & None & $0.274 \pm 0.001$ & 204 & $0.274 \pm 0.001$ & 267 & 0.342 \\
\hline & $\mathrm{B}$ & None & $0.272 \pm 0.001$ & 98 & $0.274 \pm 0.001$ & 373 & 0.060 \\
\hline & $\mathrm{C}$ & None & $0.273 \pm 0.001$ & 359 & $0.275 \pm 0.001$ & 112 & 0.084 \\
\hline & A & $\mathrm{B}, \mathrm{C}$ & $0.273 \pm 0.001$ & 204 & $0.274 \pm 0.001$ & 267 & 0.527 \\
\hline & B & $\mathrm{A}, \mathrm{C}$ & $0.272 \pm 0.001$ & 98 & $0.275 \pm 0.001$ & 373 & 0.010 \\
\hline & $\mathrm{C}$ & A, B & $0.272 \pm 0.001$ & 359 & $0.275 \pm 0.001$ & 112 & 0.010 \\
\hline \multirow[t]{6}{*}{ Shoulder yield\% } & A & None & $0.325 \pm 0.001$ & 204 & $0.325 \pm 0.001$ & 267 & 0.952 \\
\hline & $\mathrm{B}$ & None & $0.325 \pm 0.001$ & 98 & $0.325 \pm 0.001$ & 373 & 0.872 \\
\hline & $\mathrm{C}$ & None & $0.325 \pm 0.001$ & 359 & $0.324 \pm 0.001$ & 112 & 0.353 \\
\hline & A & $\mathrm{B}, \mathrm{C}$ & $0.325 \pm 0.001$ & 204 & $0.324 \pm 0.001$ & 267 & 0.735 \\
\hline & B & $\mathrm{A}, \mathrm{C}$ & $0.325 \pm 0.001$ & 98 & $0.324 \pm 0.001$ & 373 & 0.550 \\
\hline & $\mathrm{C}$ & $\mathrm{A}, \mathrm{B}$ & $0.325 \pm 0.001$ & 359 & $0.324 \pm 0.001$ & 112 & 0.275 \\
\hline
\end{tabular}


Table 3. Association of GDF8 allele copy number with various assessments of yield

\begin{tabular}{|c|c|c|c|c|c|c|c|c|}
\hline \multirow{2}{*}{ Trait } & \multirow{2}{*}{$\begin{array}{c}\text { Allele } \\
\text { being } \\
\text { assessed }\end{array}$} & \multicolumn{6}{|c|}{$\mathbf{L S M} \pm \mathbf{S E}$} & \multirow{2}{*}{ P-value } \\
\hline & & Allele absent & $\mathbf{N}$ & Allele 1 copy & $\mathbf{N}$ & Allele 2 copy & $\mathbf{N}$ & \\
\hline \multirow[t]{3}{*}{ Leg yield (Kg) } & $\mathrm{A}$ & $21.566 \pm 0.088$ & 204 & $21.646 \pm 0.085$ & 218 & $21.813 \pm 0.120$ & 49 & 0.321 \\
\hline & B & $21.648 \pm 0.117$ & 98 & $21.693 \pm 0.084$ & 234 & $21.505 \pm 0.099$ & 139 & 0.226 \\
\hline & $\mathrm{C}$ & $21.632 \pm 0.074$ & 359 & $21.586 \pm 0.115$ & 110 & $22.211 \pm 0.708$ & 2 & 0.644 \\
\hline \multirow[t]{3}{*}{ Loin yield (Kg) } & A & $14.744 \pm 0.069$ & 204 & $14.762 \pm 0.067$ & 218 & $14.677 \pm 0.215$ & 49 & 0.801 \\
\hline & B & $14.646 \pm 0.091$ & 98 & $14.854 \pm 0.065$ & 234 & $14.635 \pm 0.077$ & 139 & 0.015 \\
\hline & $\mathrm{C}$ & $14.723 \pm 0.058$ & 359 & $14.811 \pm 0.090$ & 110 & $15.357 \pm 0.553$ & 2 & 0.363 \\
\hline \multirow{3}{*}{$\begin{array}{l}\text { Shoulder yield } \\
\text { (Kg) }\end{array}$} & A & $17.449 \pm 0.068$ & 204 & $17.489 \pm 0.066$ & 218 & $17.544 \pm 0.124$ & 49 & 0.740 \\
\hline & B & $17.446 \pm 0.091$ & 98 & $17.530 \pm 0.065$ & 224 & $17.409 \pm 0.077$ & 139 & 0.331 \\
\hline & $\mathrm{C}$ & $17.483 \pm 0.058$ & 359 & $17.445 \pm 0.090$ & 110 & $17.756 \pm 0.551$ & 2 & 0.795 \\
\hline \multirow[t]{3}{*}{ Total yield (Kg) } & A & $53.759 \pm 0.188$ & 204 & $53.897 \pm 0.182$ & 218 & $54.033 \pm 0.343$ & 49 & 0.685 \\
\hline & B & $53.741 \pm 0.250$ & 98 & $54.077 \pm 0.179$ & 234 & $53.550 \pm 0.212$ & 139 & 0.068 \\
\hline & $\mathrm{C}$ & $53.839 \pm 0.159$ & 359 & $53.841 \pm 0.247$ & 110 & $55.324 \pm 1.518$ & 2 & 0.621 \\
\hline \multirow[t]{3}{*}{ Leg yield\% } & A & $0.401 \pm 0.001$ & 204 & $0.401 \pm 0.001$ & 218 & $0.403 \pm 0.001$ & 49 & 0.231 \\
\hline & B & $0.403 \pm 0.001$ & 98 & $0.401 \pm 0.001$ & 234 & $0.401 \pm 0.001$ & 139 & 0.384 \\
\hline & $\mathrm{C}$ & $0.402 \pm 0.001$ & 359 & $0.401 \pm 0.001$ & 110 & $0.401 \pm 0.001$ & 2 & 0.708 \\
\hline \multirow[t]{3}{*}{ Loin yield\% } & A & $0.274 \pm 0.001$ & 204 & $0.274 \pm 0.001$ & 218 & $0.272 \pm 0.001$ & 49 & 0.148 \\
\hline & B & $0.272 \pm 0.001$ & 98 & $0.275 \pm 0.001$ & 234 & $0.273 \pm 0.001$ & 139 & 0.037 \\
\hline & $\mathrm{C}$ & $0.273 \pm 0.001$ & 359 & $0.275 \pm 0.001$ & 110 & $0.279 \pm 0.001$ & 2 & 0.180 \\
\hline \multirow[t]{3}{*}{ Shoulder yield\% } & A & $0.325 \pm 0.001$ & 204 & $0.325 \pm 0.001$ & 218 & $0.325 \pm 0.002$ & 49 & 0.972 \\
\hline & B & $0.325 \pm 0.001$ & 98 & $0.324 \pm 0.001$ & 234 & $0.325 \pm 0.001$ & 139 & 0.642 \\
\hline & $\mathrm{C}$ & $0.325 \pm 0.001$ & 359 & $0.324 \pm 0.001$ & 110 & $0.321 \pm 0.007$ & 2 & 0.569 \\
\hline
\end{tabular}

As shown in Table (2), the presence/ absence of particular allele were not found to affect birth weight, weaning weight, growth rate or draft-age. The presence of allele $\mathrm{B}$ tended to be associated with the increased percentage loin yield $(\mathrm{P}<0.06)$, while the presence of allele $\mathrm{C}$ tended to be associated with increased HCW $(\mathrm{P}<0.058)$ and increased percentage loin yield $(\mathrm{P}<0.084)$. The effect of allele $\mathrm{B}$ became significant on loin yield $(\mathrm{P}<0.026)$ and the percentage loin yield $(\mathrm{P}<0.010)$ when alleles $\mathrm{A}$ and $\mathrm{C}$ were introduced into the model. Furthermore, the effect of allele $\mathrm{C}$ on the percentage loin yield became significant $(\mathrm{P}<0.010)$ when alleles $\mathrm{A}$ and $\mathrm{B}$ were introduced into the model (Table 2). When the alleles $\mathrm{B}$ and $\mathrm{C}$ were forced into the model, the percentage loin yield became more affected by the absence/presence of allele B (absent: 0.272 0.001 , present: $0.275 \pm 0.001 ; \mathrm{P}<0.009)$ and allele $\mathrm{C}$ (absent: $0.273 \pm 0.001$, present: $0.275 \pm 0.001 ; \mathrm{P}<$ 0.012). These results suggest that the selection for the presence of either B or C allele would increase the percentage of loin yield.

The third set of analyses (Table 3 ) concerned the number of GDF8 allele copies present. The number of allele B copies significantly affected loin yield ( $\mathrm{P}$ $<0.015)$, and percentage loin yield $(\mathrm{P}<0.037)$. Having one copy of allele B was associated with increased loin yield, total yield and percentage loin yield, however having two copies of allele B was associated with decreased loin yield and total yield. In contrast to our results, Hickford et al. (2009) reported that, having two copies of allele B increases leg yield, loin yield, total yield, and percentage loin yield.

The GLMMs that were used in the three sets of analyses showed that the variation in GDF8 gene had no effect on birth weight, pre-weaning growth rate, draft age or H-W (data not shown). These results are consistent with the findings of Kijas et al. (2007) in Australian White Suffolk, Poll Dorest and Lincoln sheep and Hickford et al. (2009) in New Zealand Romney sheep. However, the genetic variation was found in intronic DNA, which makes it difficult to explain how the variation affected the activity of GDF8. Possibilities include that the intronic sequence may harbor important functional elements that affect gene expression and RNA splicing (Lomelin et al., 2010). It may also be linked to nucleotide variation in critical gene control regions (Hickford et al., 2009).

According to our results, the variation in intron 1 of GDF8 gene is correlated with loin yield and percentage loin yield and tends to correlate with the total yield. These traits are the most important carcasses traits of lambs that provide optimal returns 
to the farmers, as the loin meat is very tender and is invariably cooked using a dry-heat method and also may be de-boned to produce boneless roasts or chops that consumers prefer. These results could speculate that selection pressure for the correlated traits with this region may have reduced genotypic variation in this breed of sheep.

We could conclude that, although the variation in intron 1 of ovine GDF8 gene affected loin yield and percentage loin yield, further investigations need to be carried out to assess the effect of variation in another regions in this gene on growth and carcass traits of New Zealand Romney sheep and another breeds. Furthermore, our results proved that, PCRSSCP is an appropriate tool to detect the variability of the candidate genes affecting important traits of farm animals.

\section{REFERENCES}

Bellinge R.H.S., D.A. Liberles, S.P.A. Iaschi, P. A. O'Brien and G.K. Tay, 2005. Myostatin and its implications on animal breeding: a review. Animal Genetics, 36: 1-6.

Boman I.A., G. Klemetsdal, O. Nafstad, T. Blichfeldt and D. I. Vage, 2010. Impact of two myostatin (MSTN) mutations on weight gain and lamb carcass classification in Norwegian White Sheep (Ovis aries). Genetic, Selection, Evolution, 42:4.

Byun S. O., Q. Fang, H. Zhou and J. G. H. Hickford, 2009. An effective method for silver-staining DNA in large numbers of polyacrylamide gels. Analytical Biochemistry, 385:174-175

Clop A., F. Marcq, H. Takeda, D. Pirottin, X. Tordoir, B. Bibé, J. Bouix, F. Caiment, J. M. Elsen, F. Eychenne, C. Larzul, E. Laville, F. Meish, D. Milenkovic, J. Tobin, C. Charlier and M. Georges, 2006. A mutation creating a potential illegitimate microRNA target site in the myostatin gene affects muscularity in sheep. Nature Genetics, 38: 813-818.

Grisolia A., G. Angelo, L. Porto Neto, F. Siqueira and J. Garcia, 2009. Myostatin (GDF8) single nucleotide polymorphisms in Nellore cattle. Genetics and Molecular Research, 8: 822-830.

Grobet L., L. J. Martin, D. Poncelet, D. Pirottin, B. Brouwers, J. Riquet, A. Schoeberlein, S. Dunner, F. Ménissier, J. Massabanda, R. Fries, R. Hanset and M. Georges, 1997. A deletion in the bovine myostatin gene causes the double-muscled phenotype in cattle. Nature Genetics, 17: 71-74.

Hadjipavlou G., O. Matika, A. Clop and S. C. Bishop, 2008. Two single nucleotide polymorphisms in the myostatin (GDF8) gene have significant association with muscle depth of commercial Charollais sheep. Animal Genetics, 39: 346-353.

Han J., H. Zhou, R. H. Forrest, J. R. Sedcole, C. M. Frampton and J. G. H. Hickford, 2010. Effect of myostatin (MSTN) g+6223G $>$ A on production and carcass traits in New Zealand Romney sheep.
Asian Australian Journal of Animal Science, 23: $863-866$.

Haynes F., P. Greenwood, M. Mcdonagh, C. Mcmahon, G. Nicholas, C. Berry and V. Oddy, 2013. Lack of association between allelic status and myostatin content in lambs with the myostatin $\mathrm{g}+6723 \mathrm{G}>\mathrm{A}$ allele. Journal of Animal Science, 91: 78-89.

Hickford J. G. H., R. H. Forrest, H. Zhou, Q. Fang, J. Han, C. M. Frampton and A. L. Horrell, 2009. Polymorphisms in the ovine myostatin gene (MSTN) and their association with growth and carcass traits in New Zealand Romney sheep. Animal Genetics, 41:64-72.

Hopkins D. L., E. Safari, J. M. Thompson and C. R. Smith, 2004. Video image analysis in the Australian meat industry - precision and accuracy of predicting lean meat yield in lamb carcasses. Meat Science, 67: 269-274.

Johnson, P. L., K. G. Dodds, W. E. Bain, G. J. Greer, N. J. McLean, R. J. McLaren, S. M. Galloway, T. C. van Stijn and J. C. McEwan, 2009. Investigations into the GDF8 g+6273 G-A polymorphism in New Zealand Texel sheep. Journal of Animal Science, 87:1856-1864.

Kambadur R., M. Sharma, T. P. L. Smith and J. J. Bass, 1997. Mutations in myostatin (GDF8) in double-muscled Belgian Blue and Piedmontese cattle. Genome Research, 7: 910-915.

Kijas J. M., R. McCulloch, J. E. Hocking Edwards, V. H. Oddy, S. H. Lee and J. van der Werf, 2007. Evidence for multiple alleles affecting muscling and fatness at the ovine GDF8 locus. BMC Genetics, 8: 80.

Lin J., H. B. Arnold, M. A. Della-Fera, M. J. Azain, D. L. Hartzell and C. A. Baile, 2002. Myostatin knockout in mice increases myogenesis and decreases adipogenesis. Biochemical and Biophysical Research Communications, 291: 701-706.

Lomelin D., E. Jorgenson and N. Risch, 2010. Human genetic variation recognizes functional elements in noncoding sequence. Genome Research, 20: 311-319.

Marchitelli C., M. C. Savarese, A. Crisa, A. Nardone, P. A. Marsan and A. Valentini, 2003. Double muscling in Marchigiana beef breed is caused by a stop codon in the third exon of myostatin gene. Mammalian Genome, 14: 392-395.

McPherron A. C., A. M. Lawler and S. J. Lee, 1997. Regulation of skeletal muscle mass in mice by a new TGF-b superfamily member. Nature, 387: 83-90.

McPherron A. C. and S. J. Lee, 1997. Double muscling in cattle due to mutations in the myostatin gene. Proceedings of the National Academy of Sciences of the United States of America, 94: 12457-12461.

McPherron A. C. and S. J. Lee, 2002. Suppression of body fat accumulation in myostatin-deficient mice. The Journal of Clinical Investigation, 109: 595-601. 
Mendias C. L., K. I. Bakhurin and J. A. Faulkner, 2008. Tendons of myostatin-deficient mice are small, brittle, and hypocellular. Proceedings of the National Academy of Sciences of the United States of America, 105: 388-393.

Schuelke M., K. R. Wagner, L. E. Stolz, C. Hubner, T. Riebel, W. Komen, T. Braun, J. F. Tobin and S. J. Lee, 2004. Myostatin mutation associated with gross muscle hypertrophy in a child. New England Journal of Medicine, 350: 2682-2688.

Szabo' G., G. Dallmann, G. Muller, L. Patthy, M. Soller and L. Varga, 1998. A deletion in the myostatin gene causes the compact (Cmpt) hypermuscular mutation in mice. Mammalian Genome, 9: 671-672.

Whittemore L. A., K. Song, X. Li, J. Aghajanian, M. Davies, S. Girgenrath, J. J. Hill, M. Jalenak, P. Kelley, A. Knight, R. Maylor, D. O'Hara, A. Pearson, A. Quazi, S. Ryerson, X. Y. Tan, K. N. Tomkinson, G. M. Veldman, A. Widom, J. F. Wright, S. Wudyka, L. Zhao and N. M. Wolfman,
2003. Inhibition of myostatin in adult mice increases skeletal muscle mass and strength. Biochemical and Biophysical Research Communications, 300: 965-971.

Wiener P., J. A. Smith, A. M. Lewis, J. A. Woolliams and J. L. Williams, 2002. Muscle-related traits in cattle: the role of the myostatin gene in the South Devon breed. Genetics Selection Evolution, 34: 221-232.

Zhou H., J. G. Hickford and Q. Fang, 2006. A twostep procedure for extracting genomic DNA from dried blood spots on filter paper for polymerase chain reaction amplification. Analytical Biochemistry, 354: 159-161.

Zhou H., J .G .H. Hickford and Q. Fang, 2008. Variation in the coding region of the myostatin (GDF8) gene in sheep. Molecular and Cellular Probes, 22: 67-68. 
التباين في منطقة الأنترون 1 لجين GDF8 وارتباطه مع صفات النمو والذبيحة في الأغنام ثنائية الغرض

عادل حسيني محمد إبراهيم' ، هوتونج زهاو ‘، جوناثان هيكفورد'

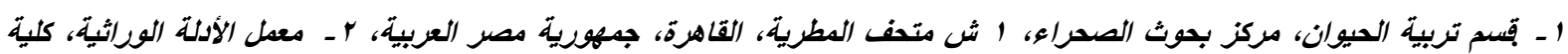

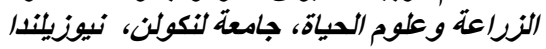

ـ تعتبر صفات النمو و الذبيحة من أهم الصفات ذات القيمة الاقتصادية في الأغنام ، و هذه الصفات ذات طبيعة كمية حيث يتحكم فيها عدد كبير من

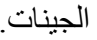
ـ تتتم حتى الآن عملية التحسين الور اثي لهذه الصفات باستخدام الطرق التقليدية للانتخاب التي تعتمد على تسجيل القيم المظهرية للصفة المرغوب

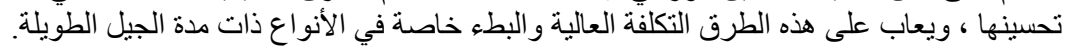

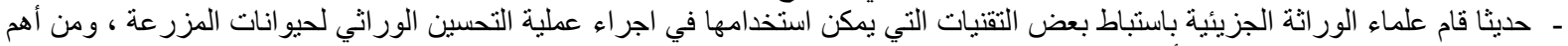

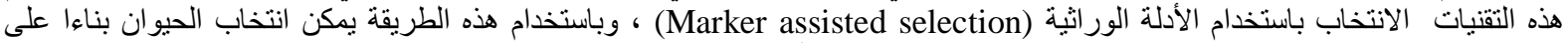

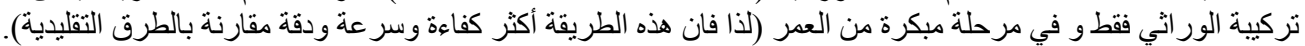

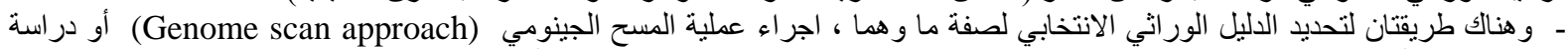

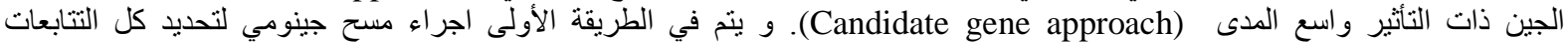

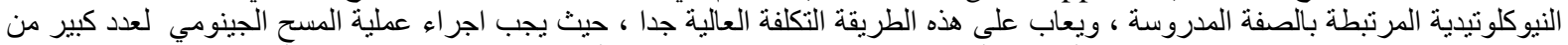

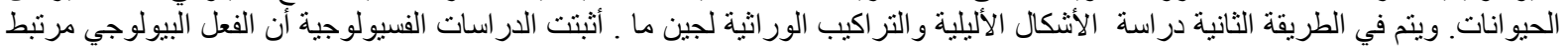

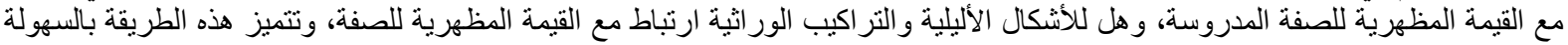
وقلة التكلقة.

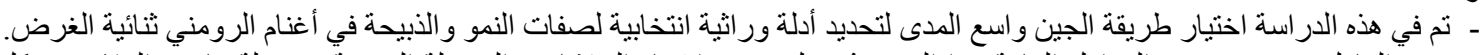

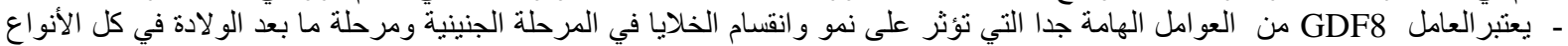

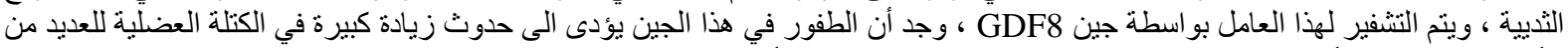

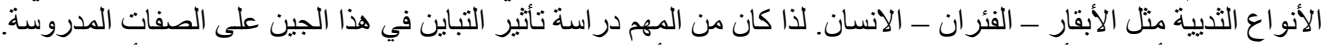

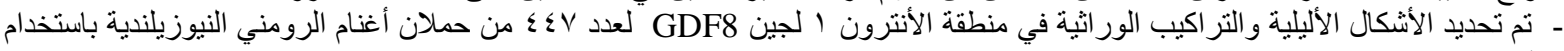

تقنية PCR-SSCP

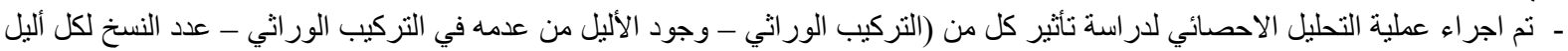

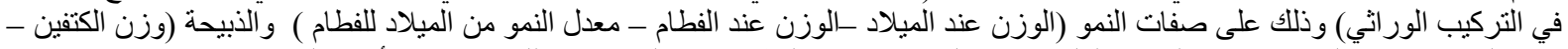

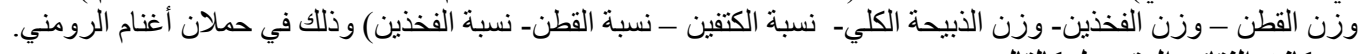
- وكانت النتائج المتحصل كالتالي الفخدن

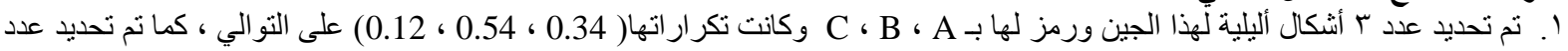

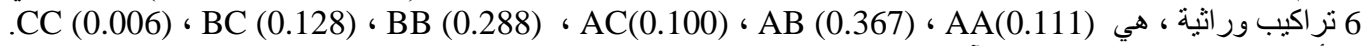

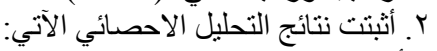

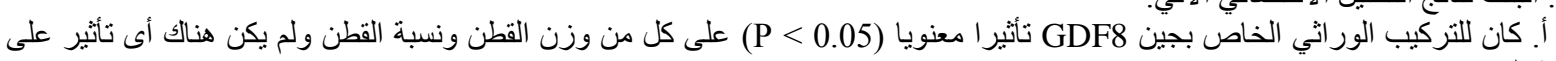

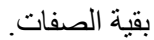

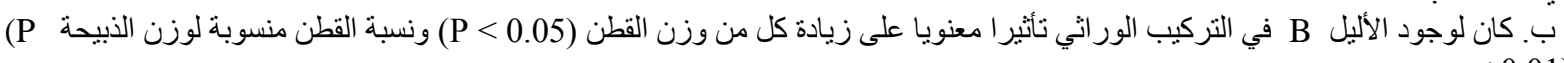
. $<0.01)$

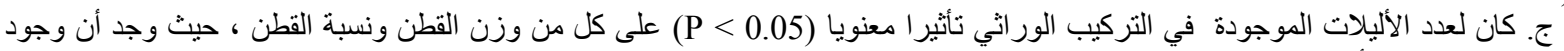

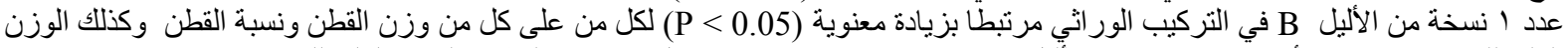

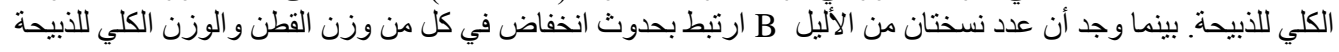
التوصيات:

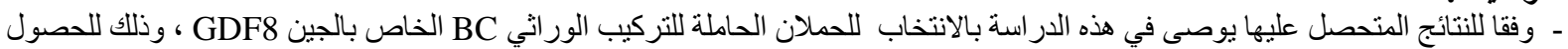

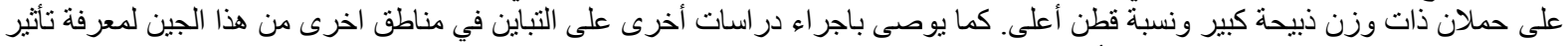
هذا الجين على صفات النمو و الذبيحة في الأغنام. 